\title{
Pengaruh citra sekolah dan biaya pendidikan terhadap keputusan siswa untuk melanjutkan pendidikan ke SMK
}

\author{
Udin Ahidin*) \\ Universitas Pamulang, Indonesia
}

\begin{tabular}{l} 
Article Info \\
\hline Article history: \\
Received Jun $23^{\text {rd }}, 2021$ \\
Revised Jul $19^{\text {th }}, 2021$ \\
Accepted Aug $04^{\text {th }}, 2021$ \\
\hline
\end{tabular}

\section{Keyword:}

Citra sekolah

Biaya pendidikan

Keputusan siswa

\begin{abstract}
Tujuan penelitian untuk mengetahui pengaruh citra sekolah dan biaya pendidikan terhadap keputusan siswa untuk melanjutkan pendidikan ke SMK di wilayah Daerah Istimewa Yogyakarta. Populasi dalam penelitian ini berjumlah 88.523 siswa yang diambil berdasar jumlah siswa tahun 2020 . Dalam pengambilan sampel penulis memakai non probability sampling dan digunakan rumus Slovin dengan tingkat error $10 \%$ dan diperoleh sampel sebanyak 100 siswa. Dalam mengumpulkan data digunakan metode survey, dokumentasi dan studi literatur serta kuesioner. Metode analisis data dalam pengujian ini digunakan analisis statistik yang meliputi pengujian regresi, koefisien korelasi, koefisien determinasi dan uji hipotesis. Berdasarkan hasil penelitian menunjukkan bahwa terdapat citra sekolah berpengaruh signifikan terhadap terhadap keputusan siswa untuk melanjutkan pendidikan ke SMK. Biaya pendidikan berpengaruh signifikan terhadap terhadap keputusan siswa untuk melanjutkan pendidikan ke SMK. Citra sekolah dan biaya pendidikan secara simultan berpengaruh signifikan terhadap keputusan siswa untuk melanjutkan pendidikan ke SMK.
\end{abstract}

(C) 2021 The Authors. Published by IICET.

This is an open access article under the CC BY-NC-SA license

(https://creativecommons.org/licenses/by-nc-sa/4.0)

\section{Corresponding Author:}

Udin Ahidin,

Universitas Pamulang

Email: dosen00406@unpam.ac.id

\section{Pendahuluan}

Lulusan SMK bertujuan untuk menyiapkan generasi lulusan untuk memasuki dunia kerja dan memiliki peranan strategis kualitas sumber daya manusia khususnya tenaga kerja tingkat menengah. Oleh karena itu sekolah kejuruan harus mampu menghasilkan lulusan yang berkualitas guna bersaing dengan lulusan sekolah lainnya agar siswa lulusan mampu berkompetisi didunia kerja baik disektor pemerintahan, industri maupun menciptakan usaha menegah.

Daerah Istimewa Yogyakarta yang dikenal dengan kota pendidikan memiliki 4 kabupaten dan 1 kota yaitu Kabupaten Bantul, Sleman, Gunungkidul, Kulon Progo dan Kota Yogyakarta memiliki penyebaran sekolah untuk jenjang SD, SMP, SMA, SMK sampai PT yang hampir merata, dan menjangkau seluruh wilayah sampai ke pelosok desa dan kecamatan kecuali untu perguruan tinggi belum semua kecamatan memiliki.

Input SMK yaitu siswa yang telah lulus jenjang SMP/MTs sebagai program wajib belajar 9 yang dicanangkan pemerintah. Adapun sebaran SMK yang ada di Wilayah Daerah Istimewa Yogyakarta berdasarkan jumlah seklah swasta dan negeri serta keadaan guru dan jumlah siswa disajikan Tabel 1. 
Tabel 1. Sebaran Jumlah Sekolah SMK di Wilayah Daerah Istimewa Yogyakarta Tahun 2020

\begin{tabular}{lcccc}
\hline \multicolumn{1}{c}{ Kabupaten } & \multicolumn{2}{c}{ Jumlah Sekolah SMK } & Jumlah & Jumlah siswa \\
\cline { 2 - 3 } Kabupaten Bantul & SMK Negeri & SMK Swasta & Guru & Keseluruhan \\
Kabupaten Sleman & 13 & 36 & 1.459 & 18.534 \\
Kabupaten Gunungkidul & 8 & 49 & 1.573 & 23.153 \\
Kabupaten Kulon Progo & 13 & 34 & 1.221 & 19.046 \\
Kota Yogyakarta & 8 & 28 & 958 & 11.008 \\
& 8 & 22 & 1.172 & 16.782 \\
& 50 & 169 & 6.383 & 88.523 \\
\hline
\end{tabular}

Sumber: datapokokditsmk, 2020

Berdasarkan Tabel 1 menunjukkan bahwa sebaran sekolah antar kabupaten di wilayah Daerah Istimewa Yogyakarta jumlahnya beragam. Kabupaten Bantul memiliki SMK baik negeri maupun swasta sebanyak 36 sekolah dengan jumlah seluruhnya 18.534. Kemudian kabupaten Sleman memiliki 49 sekolah SMK jumlah ini paling banyak diantara kabupaten lainnya dengan jumlah siswa 23.153. Untuk Kabupaten Gunungkidul memiliki 34 SMK dengan 19.046 siswa, kemudian kabupaten kulon progo memiliki 28 SMK dengan jumlah siswa 11.008 dan kota Yogyakarta memiliki SMK sebanyak 22 dengan jumlah siswa 16.782.

Perkembangan dan persaingan input siswa tidak dapat dipungkiri, pendidikan telah mengarah pada proses industrialisasi, semakin banyaknya input siswa yang masuk pada sekolah akan meraih keuntungan pada pendapatan sekolah. Sekolah bukan hanya dunia pendidikan dan sosial, namun dapat berubah menjadi lembaga bisnis dan jasa yang menguntungkan. Sekolah dapat dikatakan sebagai lembaga industri yang harus di kelola secara professional. Semakin ketatnya persaingan menuntut manajemen sekolah dan sumber daya dkelola secara baik.

Tantangan dalam persaingan sekolah semakin ketat, banyaknya penawaran jasa yang tinggi, menigkatnya tuntutan siswa pada kualitas dan biaya, kemajuan teknologi komunikasi, informasi yang merubah dari segi kehidupan. Selain mutu sekolah, para orang tua juga mempertimbangkan persepsi terhadap citra (image) sekolah. Citra atau image sekolah yang bermutu menjadi salah satu hal penting dan menjadi pertimbangan siswa maupun orang tua ketika memilih sekolah sebagai tempat menempuh pendidikan. Persepsi membentuk citra sebuah organisasi. Apabila citra baik sudah terbentuk maka secara otomatis akan menjadi asset media sangat efektif dan efisien. Citra sekolah baik akan menjadi salah satu pertimbangan pengambilan keputusan orang tua atau siswa untuk menentukan pilihan terhadap sekolah.

Pemilihan siswa dalam menentukan pilihan sekolah juga mempertimbangkan biaya pendidikan yang ditetapkan oleh lembaga sekolah. Sebenarnya pemerintah setiap tahunnya selalu menganggarkan alokasi subsidi kepada lembaga pendidikan yang bersarnya tidak sedikit seperti penyaluran biaya operasional pendidikan (BOP) yang diberikan Pemkot dari APBD ke sekolah-sekolah di wilayahnya. Namun pada kenyataannya subsidi yang diberikan belum semuanya mampu mencukupi kebutuhan operasional sekolah sehingga terkadang pemerintah Daerah tidak mampu membatasi pembatasan tarikan SPP yang dilakukan oleh sekolah dan ini merupakan implikasi dari penyaluran biaya operasional pendidikan (BOP) yang diberikan Pemkot dari APBD ke Sekolah masih kecil.

Kondisi sekolah menetapkan biaya bagi siswa dengan besaran yang bervariasi antara satu sekolah dengan sekolah lainnya. Disamping itu sekolah juga masih dimungkinkan untuk meminta sumbangan dari orang tua siswa namun untuk keperluan investasi. Keperluan investasi misalkan membangun ruang kelas baru atau pengadaan alat labolatorium meskipun hal ini sudah dicantumkan dalam rencana anggaran pendidikan sekolah namun sering dirasakan oleh masyarakat masih memberatkan karena masih tinggi.

Tujuan pendidikan sebagai suatu organisasi yang diharapkan mampu mengelola sumber daya untuk meningkatkan kualitas untuk meningkatkan animo masyarakat dan siswa untuk menentukan melanjutkan ke sekolah. Pertimbangan siswa menjadi factor penting dalam pengambilan keputusan yang disesuaikan dengan keadaan atau kondisi yang ada. Pemilihan keputusan dalam menentukan pilihan berbagai alernatif, keadaan, dan kesamaan sehingga dipengaruhi oleh banyak faktor baik emosi, pikiran, logika, serta kemantapan hati siswa atau orang tua melalui persepsi dan citra sekolah. Variabel yang digunakan meliputi:

\section{Citra Sekolah}

Persepsi, gambaran seseorang dan masyarakat mengenai organisasi atau produknya disebut Image sekolah atau citra sekolah. Citra sekolah bersumber dari informasi pengetahuan dan pemahaman mengenai produk atau organisasi tersebut (Bukhari Alma, 2003). Citra sekolah baik akan memunculkan perspesi yang baik bagi orang, dan begitu juga sebaliknya. 


\section{Biaya Pendidikan}

Biaya pendidikan adalah biaya penyelenggaraan dan pembinaan pendidikan serta layanan administrasi akademik (Supriadi, 2010). Biaya dalam bentuk natura (barang), pengorbanan peluang, maupun uang untuk mengelola dan melaksanakan proses pendidikan.

\section{Keputusan Siswa}

Keputusan siswa didefinisikan sebagai kecenderungan hati yang tinggi terhadap sesuatu (Kamus Besar Bahasa Indonesia, 2019). Adapun siswa adalah orang yang sedang berguru/belajar atau bersekolah. Keputusan siswa dalam penelitian menunjukan kecenderungan siswa untuk mengambil keputusan dalam memilih SMK sebagai sekolah lanjutan mereka.

Berdasarkan pemaparan yang sudah pada latar belakang di atas, maka dalam penelitian ini dirumuskan masalah sebagai beikut: 1) Adakah pengaruh yang signifikan citra sekolah terhadap keputusan siswa untuk melanjutkan pendidikan ke SMK di wilayah Daerah Istimewa Yogyakarta?; 2) Adakah pengaruh yang signifikan biaya pendidikan terhadap keputusan siswa untuk melanjutkan pendidikan ke SMK di wilayah Daerah Istimewa Yogyakarta?; 3) Adakah pengaruh yang signifikan secara simultan citra sekolah dan biaya pendidikan terhadap keputusan siswa untuk melanjutkan pendidikan ke SMK di wilayah Daerah Istimewa Yogyakarta?

Berdasarkan rumusan masalah yang sudah ditetapkan di atas, maka tujuan penelitian adalah sebagai berikut: 1) Untuk mengetahui pengaruh citra sekolah terhadap keputusan siswa untuk melanjutkan pendidikan ke SMK di wilayah Daerah Istimewa Yogyakarta; 2) Untuk mengetahui pengaruh biaya pendidikan terhadap keputusan siswa untuk melanjutkan pendidikan ke SMK di wilayah Daerah Istimewa Yogyakarta; 3) Untuk mengetahui pengaruh secara simultan citra sekolah dan biaya pendidikan terhadap keputusan siswa untuk melanjutkan pendidikan ke SMK di wilayah Daerah Istimewa Yogyakarta.

Sugiyono (2018) "Model penelitian merupakan sintesa yang mencerminkan keterkaitan antara variabel yang diteliti dan merupakan tuntunan untuk memecahkan masalah penelitian serta merumuskan hipotesis yang berbentuk bagan alur yang dilengkapi penjelasan kualitatif'. Paradigma penelitian disajikan pada Gambar 1.

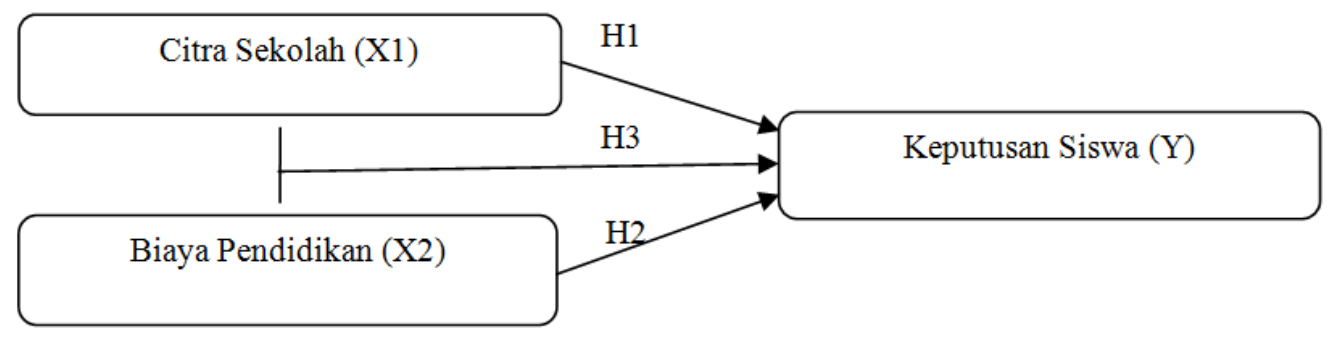

Gambar 1. Paradigma Model Penelitian

Sugiyono (2017:63) berpendapat "hipotesis merupakan jawaban sementara terhadap rumusan masalah penelitian, dimana rumusan masalah dinyatakan dalam kalimat pernyataan". hipotesis penelitian sebagai berikut:

H1 : Diduga terdapat pengaruh yang signifikan citra sekolah terhadap keputusan siswa untuk melanjutkan pendidikan ke SMK di wilayah Daerah Istimewa Yogyakarta.

H2 : Diduga terdapat pengaruh yang signifikan biaya pendidikan terhadap keputusan siswa untuk melanjutkan pendidikan ke SMK di wilayah Daerah Istimewa Yogyakarta.

H3 : Diduga terdapat pengaruh yang signifikan citra sekolah dan biaya pendidikan secara simultan terhadap keputusan siswa untuk melanjutkan pendidikan ke SMK di wilayah Daerah Istimewa Yogyakarta.

\section{Metode}

Jenis Penelitian dalam peneitian ini adalah kuantitatif, dimana menurut Sugiyono (2017:8) menyatakan penelitian kuantitatif adalah: "Metode penelitian yang berlandaskan pada filsafat positivisme, digunakan untuk meneliti pada populasi atau sampel tertentu, pengumpulan data menggunakan instrument penelitian, analisis data bersifat kuantutatif atau statistik, dengan tujuan untuk menguji hipotesis yang telah ditetapkan". Adapun pendekatan dalam penelitian ini digunakan deskriptif dan verifikatif. Populasi dalam penelitian ini adalah siswa yang melanjutkan pendidikan di SMK di Daerah Istimewa Yogyakarta. Populasi menunjukan wilayah generalisasi hasil penelitian berdasarkan objek kriteria yang akan diteliti. Menurut Sugiyono (2017) 
mendefinisikan "populasi adalah jumlah wilayah generalisasi yang terdiri atas obyek atau subyek yang mempunyai kualitas dan karakteristik yang ditetapkan oleh peneliti dan kemudian ditarik kesimpulannya". Populasi penelitian yaitu siswa yang melanjutkan pendidikan di SMK negeri maupun swasta di Daerah Istimewa Yogyakarta berjumlah 88.523 siswa.

Teknik dalam pengambilan sampel penulis menggunakan non probability sampling, oleh karena jumlah populasinya banuyak, maka dalam mendapatkan sampel digunakan rumus Slovin. Setelah dilakukan perhitungan maka diperoleh sampel sebanyal 100 responden/siswa. Teknik dalam pengumpulan data, penulis menggunakan penyebaran kuesioner berupa instrumen atau alat ukur yang digunakan untuk mengumpulkan data primer dalam penelitian ini berupa pertanyaan formal untuk memperoleh informasi dari responden/siswa dan dibobot dengan sala likert. Teknik analisis data dalam penelitian ini menggunakan beberapa alat uji, antara lain: 1) Analisis deskriptif, 2) Uji Instrumen yang meliputi uji validitas dan uji reliabilitas. 3) Uji asumsi klasik yang meliputi : (a) uji normalitas, (b) uji multikolinieritas, (c) uji autokorelasi, (d) uji heteroskedastisitas. 4) uji statistik yang meliputi: (a) analisis regresi, (b) koefisien korelasi, (c) koefisien determinasi, dan (d) pengujian hipotesis baik secara parsial maupun secara simultan

\section{Hasil dan Pembahasan}

\section{Analisis Deskriptif}

Pengujian menunjukan gejala pusat data masing masing variable. Adapun hasilnya disajikan pada Tabel 2.

Tabel 2. Hasil Analisis Descriptive Statistics

\begin{tabular}{lcrrrr}
\hline & \multicolumn{3}{c}{ Descriptive Statistics } & & \\
& $\mathrm{N}$ & Minimum & Maximum & Mean & Std. Deviation \\
Citra Sekolah (X1) & 100 & 31 & 48 & 37.88 & 3.991 \\
Biaya Pendidikan (X2) & 100 & 31 & 46 & 38.30 & 3.549 \\
Keputusan Siswa (Y) & 100 & 32 & 46 & 38.86 & 3.505 \\
Valid N (listwise) & 100 & & & & \\
\hline
\end{tabular}

Citra sekolah diperoleh mean score sebesar 3,788 dengan standar deviasi 3,991. Biaya pendidikan diperoleh mean score sebesar 3,830 dengan standar deviasi 3,549. Keputusan siswa diperoleh mean score sebesar 3,886 dengan standar deviasi 3,505. Dari hasil tersebut mean score tertinggi diperoleh variabel keputusan siswa.

\section{Uji Intrumen}

Dari hasil pengujian diperoleh seluruh item kuesioner variabel citra sekolah, biaya pendidikan dan Keputusan siswa diperoleh nilai signifikansi 2 tailed sebesar $0,000<0,05$, dengan demikian instrumen valid. Dari hasil pengujian reliabilitas atas variabel citra sekolah, biaya pendidikan dan Keputusan siswa diperoleh nilai hasil sebagai berikut:

Tabel 3. Hasil Pengujian Reliabilitas

\begin{tabular}{lcll}
\hline Cronbach's Alpha & Reliability Statistics & N of Items & 10 \\
\hline & .743 & \\
\hline Cronbach's Alpha & Reliability Statistics & N of Items & 10 \\
\hline & .627 & & \\
\hline Cronbach's Alpha & Reliability Statistics & N of Items \\
\hline
\end{tabular}

Berdasarkan hasil keseluruhan variabel citra sekolah cronbach alpha sebesar 0,743 , biaya pendidikan sebesar 0,627 dan keputusan siswa sebesar 0,650, dimana ketiga variabel memiliki nilai cronbach alpha lebih besar dari 0,600 . Keseluruhan data dinyatakan reliabel. 


\section{Uji Asumsi Klasik}

Uji Normalitas

Berdasarkan hasil uji normalitas dengan alat uji Kolmogorov-Smirnov Test, diperoleh hasil sebagai berikut:

Tabel 4. Hasil Normalitas Kolmogorov-Smirnov Test

\begin{tabular}{|c|c|c|c|c|c|c|}
\hline & $\begin{array}{l}\text { Tests } \\
\text { Kolmo }\end{array}$ & $\begin{array}{l}\text { ormal } \\
\mathrm{V}-\mathrm{Smi}\end{array}$ & & Shap & -Will & \\
\hline $\begin{array}{l}\text { Keputusan Siswa (Y) } \\
\text { a. Lilliefors Significance Correction }\end{array}$ & $\begin{array}{r}\text { Statistic } \\
.086\end{array}$ & $\begin{array}{l}\mathrm{df} \\
100\end{array}$ & $\begin{array}{l}\text { Sig. } \\
.066\end{array}$ & $\begin{array}{r}\text { Statistic } \\
.977\end{array}$ & $\begin{array}{l}\mathrm{df} \\
100\end{array}$ & $\begin{array}{l}\text { Sig. } \\
.080\end{array}$ \\
\hline
\end{tabular}

Berdasarkan hasil pengujian nilai signifikansi 0,066 lebih besar dari nilai $\alpha=0,050$ atau $(0,200>0,050)$. Asumsi distribusi persamaan adalah normal.

\section{Uji Multikonilieritas}

Uji multikolinearitas dilakukan dengan melihat nilai Tolerance Value dan Variance Inflation Factor (VIF). Adapun hasil pengujiannya sebagai berikut:

Tabel 5. Hasil Uji Multikolinieritas dengan Collinierity Statistic.

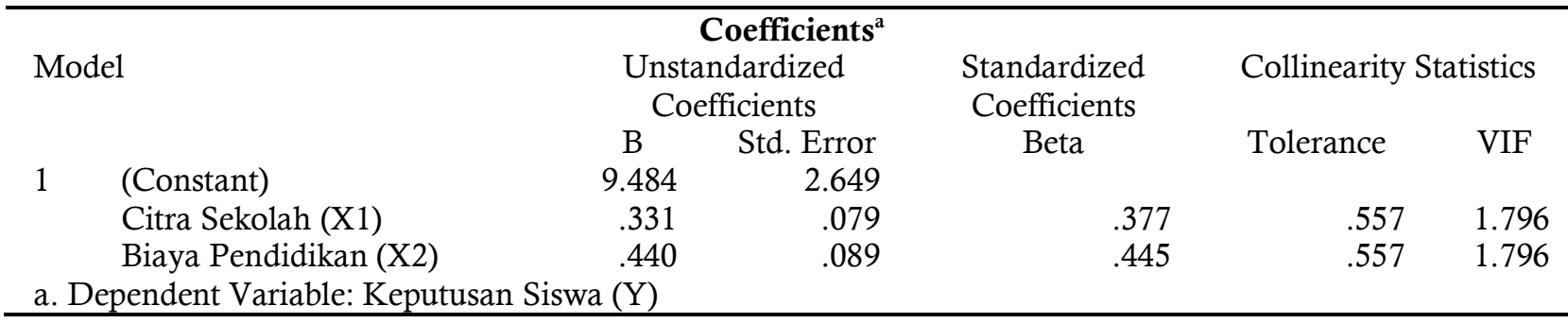

Berdasarkan hasil pengujian pada tabel diatas nilai tolerance masing-masing variabel bebas yaitu $0,557<1,0$ dan nilai Variance Inflation Factor (VIF) sebesar 1,796 < 10, dengan demikian model regresi ini tidak terjadi multikolinearitas.

Uji Autokorelasi

Pengujian dilakukan dengan alat uji Darbin-Watson (DW test). Adapun hasil pengujiannya sebagai berikut:

Tabel 6. Hasil Uji Autokorelasi

\begin{tabular}{|c|c|c|c|c|c|}
\hline \multicolumn{6}{|c|}{ Model Summary ${ }^{b}$} \\
\hline Model & $\mathrm{R}$ & R Square & $\begin{array}{l}\text { Adjusted R } \\
\text { Square }\end{array}$ & $\begin{array}{l}\text { Std. Error of the } \\
\text { Estimate }\end{array}$ & Durbin-Watson \\
\hline 1 & $.751^{\mathrm{a}}$ & .564 & .555 & 2.339 & 2.069 \\
\hline
\end{tabular}

Hasil pengujian pada tabel diatas diperoleh nilai Durbin-Watson sebesar 2,069 nilai tersebut berada diantara interval $1.550-2.460$. Dengan demikian model regresi dinyatakan tidak ada gangguan autokorelasi.

\section{Uji Heteroskedastisitas}

Pengujian heteroskedastisitas dilakukan menggunakan alat uji Glejser test dengan hasil sebagai berikut:

Tabel 7. Hasil Uji Heteroskedastisitas dengan Glejser Test Model

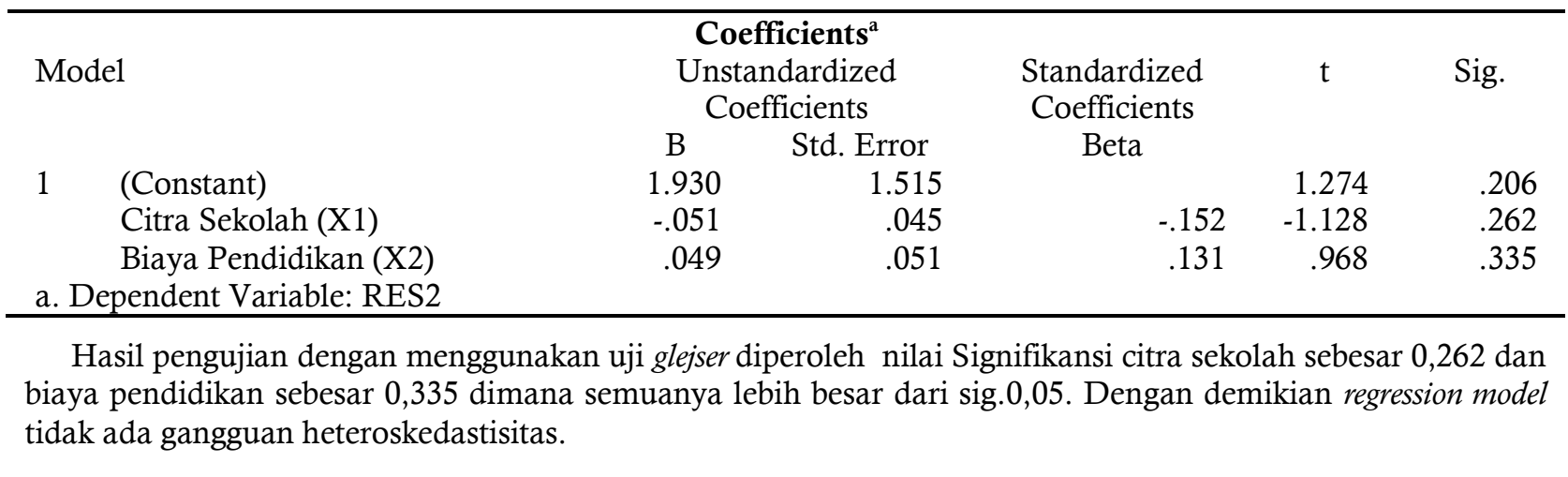




\section{Analisis Kuantitatif}

Pada analisis ini dimaksudkan untuk mengetahui pengaruh variabel independen terhadap variabel dependen. Adapun hasil pengujian sebagai berikut:

\section{Analisis Regresi Linier}

Hasil Pengujian regresi linier sederhana dan regresi linier berganda sebagai berikut:

Tabel 8. Hasil Pengujian Regresi Linier Sederhana Citra Sekolah Terhadap Keputusan Siswa

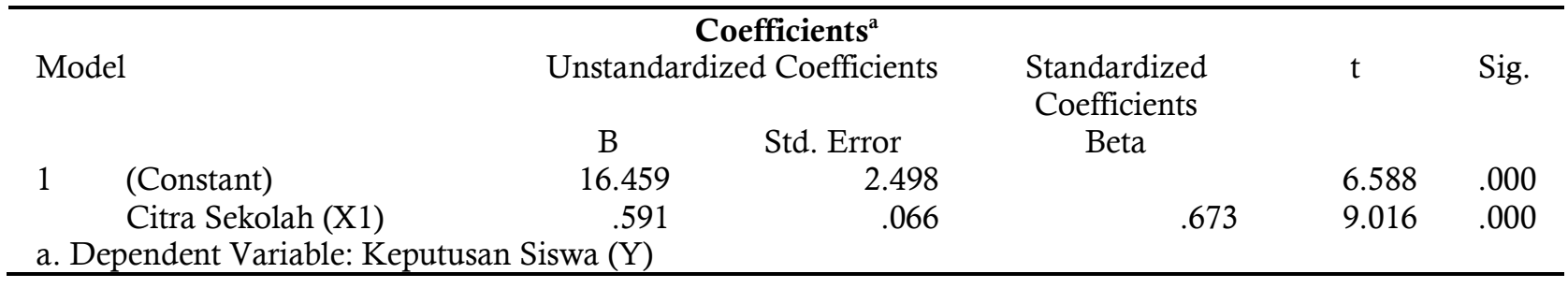

Berdasarkan hasil pengujian pada tabel di atas, diperoleh persamaan regresi $\mathrm{Y}=16,459+0,591 \mathrm{X}$. Persamaan tersebut dijelaskan sebagai berikut: 1) Diperoleh nilai konstanta sebesar 16,459 artinya, jika variabel citra sekolah dan biaya pendidikan tidak ada atau (0), maka telah terdapat nilai keputusan siswa sebesar 15,459 point; 2) Diperoleh nilai koefisien regresi variabel citra sekolah sebesar 0,591, angka positif artinya setiap ada peningkatan citra sekolah sebesar 0,591 maka keputusan siswa mengalami peningkatan sebesar 0,591 point.

Tabel 9. Hasil Pengujian Regresi Linier Sederhana Biaya Pendidikan Terhadap Keputusan Siswa

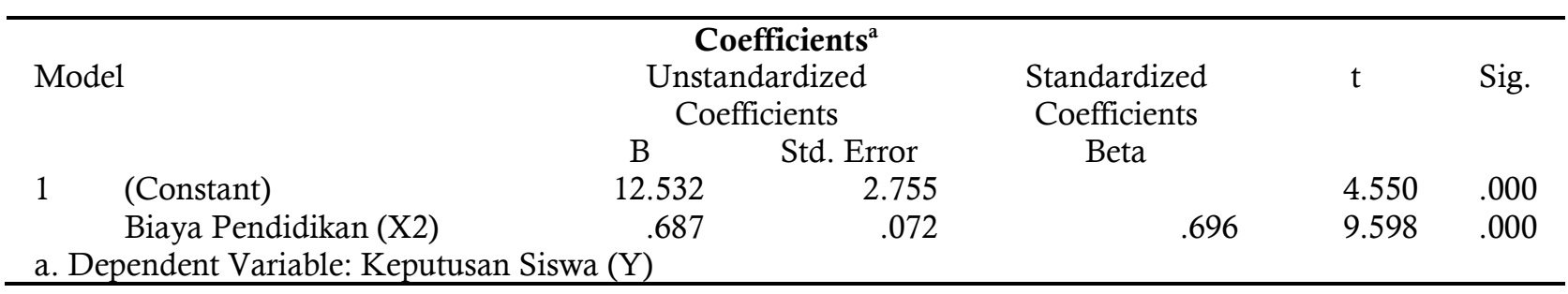

Berdasarkan hasil pengujian pada tabel di atas, diperoleh persamaan regresi $\mathrm{Y}=12,532+0,687 \mathrm{X} 2$. Persamaan tersebut dijelaskan sebagai berikut: 1) Diperoleh nilai konstanta sebesar 12,532 artinya, jika variabel citra sekolah dan biaya pendidikan tidak ada atau (0), maka telah terdapat nilai keputusan siswa sebesar 12,532 point; 2) Diperoleh nilai koefisien regresi variabel biaya pendidikan sebesar 0,687 , angka positif artinya jika biaya pendidikan semakin kompetitif sebesar 0,687 maka keputusan siswa memilih sekolah menjadi pilihannya mengalami peningkatan sebesar 0,687 point.

Tabel 10. Hasil Pengujian Regresi Linier Berganda Variabel Citra Sekolah Dan Biaya Pndidikan Secara Bersama-sama Terhadap Keputusan Siswa

\begin{tabular}{|c|c|c|c|c|c|c|}
\hline \multirow{2}{*}{\multicolumn{2}{|c|}{ Model }} & $\begin{array}{r}\text { Uns } \\
\mathrm{C}\end{array}$ & $\begin{array}{l}\text { efficients }^{\mathbf{a}} \\
\text { lardized } \\
\text { cients }\end{array}$ & $\begin{array}{l}\text { Standardized } \\
\text { Coefficients }\end{array}$ & \multirow[t]{2}{*}{$\mathrm{t}$} & \multirow[t]{2}{*}{ Sig. } \\
\hline & & B & Std. Error & Beta & & \\
\hline \multirow[t]{3}{*}{1} & (Constant) & 9.484 & 2.649 & & 3.580 & .001 \\
\hline & Citra Sekolah (X1) & .331 & .079 & 377 & 4.194 & .000 \\
\hline & Biaya Pendidikan (X2) & .440 & .089 & .445 & 4.951 & .000 \\
\hline
\end{tabular}

Berdasarkan hasil pengujian pada tabel di atas, diperoleh persamaan regresi $\mathrm{Y}=9,484+0,331 \mathrm{X} 1+$ 0,440X2. Dari persamaan tersebut dijelaskan sebagai berikut: 1) Diperoleh nilai konstanta sebesar 9,484 artinya jika citra sekolah dan biaya pendidikan tidak ada atau (0), maka terdapat nilai Keputusan siswa sebesar 9,484 point; 2) Diperoleh nilai koefisien regresi citra sekolah sebesar 0,331, angka positif artinya setiap peningkatan citra sekolah sebesar 0,331 maka Keputusan siswa mengalami peningkatan sebesar 0,331 point; 3) Diperoleh nilai koefisien regresi biaya pendidikan sebesar 0,440, angka positif artinya setiap biaya yang dtetapkan kompetitif sebesar 0,440 maka keputusan siswa mengalami peningkatan sebesar 0,440 point. 
Analisis Koefisien Determinasi

Hasil pengujian koefisien determinasi sebagai berikut:

Tabel 11. Hasil Pengujian Koefisien Determinasi Citra Sekolah Terhadap Keputusan Siswa.

\begin{tabular}{|c|c|c|c|c|}
\hline \multicolumn{5}{|c|}{ Model Summary } \\
\hline Model & $\mathrm{R}$ & R Square & $\begin{array}{c}\text { Adjusted R } \\
\text { Square }\end{array}$ & Std. Error of the Estimate \\
\hline $\begin{array}{l}1 \\
\text { a. Predi }\end{array}$ & $\begin{array}{l}.673^{\mathrm{a}} \\
\text { t), Citra Seko }\end{array}$ & .453 & .448 & 2.604 \\
\hline
\end{tabular}

Berdasarkan hasil pengujian diperoleh nilai determinasi sebesar 0,453 artinya citra sekolah memiliki kontribusi pengaruh sebesar 45,3\% terhadap keputusan siswa.

Tabel 12. Hasil Pengujian Koefisien Determinasi Biaya Pendidikan Terhadap Keputusan Siswa.

\begin{tabular}{|c|c|c|c|c|}
\hline \multicolumn{5}{|c|}{ Model Summary } \\
\hline Model & $\mathrm{R}$ & R Square & $\begin{array}{l}\text { Adjusted R } \\
\text { Square }\end{array}$ & Std. Error of the Estimate \\
\hline $\begin{array}{l}1 \\
\text { a. Predi }\end{array}$ & $\begin{array}{l}.696^{a} \\
\text { t). Biaya pen }\end{array}$ & (X2) & .479 & 2.529 \\
\hline
\end{tabular}

Berdasarkan hasil pengujian diperoleh nilai determinasi sebesar 0,485 artinya biaya pendidikan memiliki kontribusi pengaruh sebesar $48,5 \%$ terhadap keputusan siswa.

Tabel 13. Hasil Pengujian Koefisien Determinasi Citra Sekolah dan Biaya Pendidikan Terhadap Keputusan Siswa.

\begin{tabular}{|c|c|c|c|c|}
\hline \multicolumn{5}{|c|}{ Model Summary } \\
\hline Model & $\mathrm{R}$ & R Square & $\begin{array}{c}\text { Adjusted R } \\
\text { Square }\end{array}$ & Std. Error of the Estimate \\
\hline $\begin{array}{l}1 \\
\text { a. Predi }\end{array}$ & $\begin{array}{r}.751^{\mathrm{a}} \\
\mathrm{nt}), \text { Biaya pen }\end{array}$ & $\begin{array}{c}.564 \\
\text { ln (X2), Citra sek }\end{array}$ & $(\mathrm{X} 1)^{.555}$ & 2.339 \\
\hline
\end{tabular}

Berdasarkan hasil pengujian diperoleh nilai koefisien determinasi sebesar 0,564 artinya citra sekolah dan biaya pendidikan secara simultan memiliki kontribusi pengaruh sebesar 56,4\% terhadap keputusan siswa, sedangkan sisanya sebesar $43,6 \%$ dipengaruhi faktor lain.

\section{Uji Hipotesis}

Uji hipotesis Parsial (Uji t)

Pengujian hipotesis dengan uji t digunakan untuk mengetahui hipotesis parsial mana yang diterima.

Hipotesis pertama: Terdapat pengaruh yang signifikan citra sekolah terhadap keputusan siswa.

Hipotesis kedua: Terdapat pengaruh yang signifikan biaya pendidikan terhadap keputusan siswa.

Tabel 14. Hasil Uji Hipotesis Citra Sekolah Terhadap Keputusan Siswa.

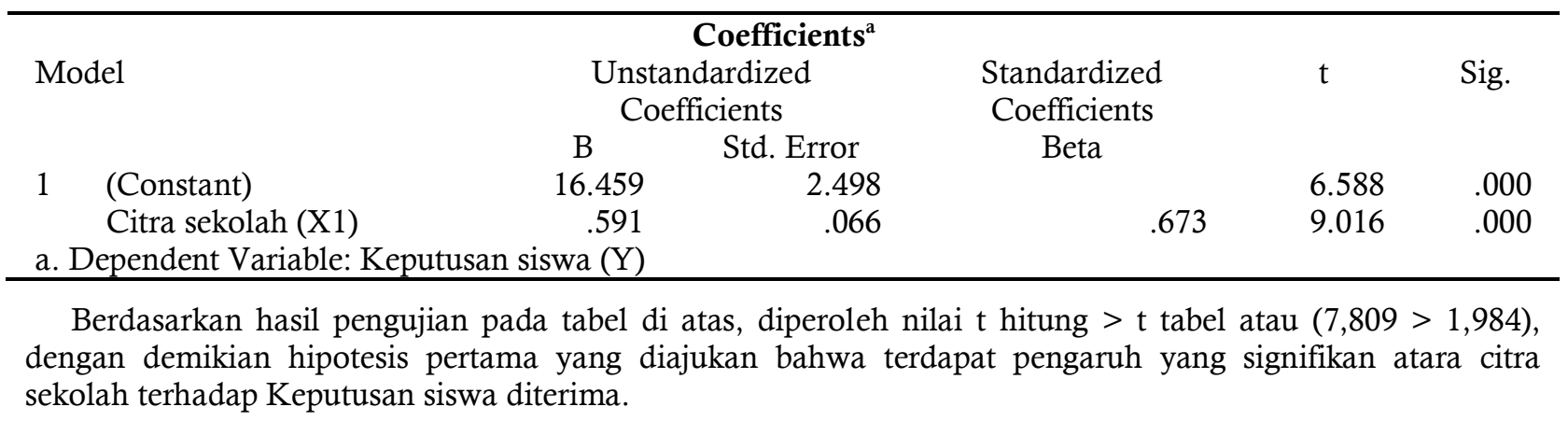


Tabel 15. Hasil Uji Hipotesis Biaya Pendidikan Terhadap Keputusan Siswa.

\begin{tabular}{|c|c|c|c|c|c|}
\hline \multirow[t]{2}{*}{ Model } & $\begin{array}{r}\text { Unst } \\
\mathrm{Cc}\end{array}$ & $\begin{array}{l}\text { efficients }{ }^{\mathrm{a}} \\
\text { ardized } \\
\text { cients }\end{array}$ & \multirow{2}{*}{$\begin{array}{c}\text { Standardized } \\
\text { Coefficients } \\
\text { Beta }\end{array}$} & \multirow[t]{2}{*}{$\mathrm{t}$} & \multirow[t]{2}{*}{ Sig. } \\
\hline & $\mathrm{B}$ & Std. Error & & & \\
\hline $1 \quad$ (Constant) & 12.532 & 2.755 & & 4.550 & .000 \\
\hline $\begin{array}{r}\text { Biaya pendidikan (X2) } \\
\text { a. Dependent Variable: Kep }\end{array}$ & $\begin{array}{c}.687 \\
\text { wa (Y) }\end{array}$ & .072 & .696 & 9.598 & .000 \\
\hline
\end{tabular}

Berdasarkan hasil pengujian pada tabel di atas, diperoleh nilai t hitung $>\mathrm{t}$ tabel atau $(8,595>1,984)$, dengan demikian hipotesis kedua yang diajukan bahwa terdapat pengaruh yang signifikan atara biaya pendidikan terhadap keputusan siswa diterima.

Uji Hipotesis Simultan (Uji F)

Pengujian hipotesis dengan uji $\mathrm{F}$ digunakan untuk mengetahui hipotesis simultan yang mana yang diterima. Hipotesis ketiga Terdapat pengaruh yang signifikan antara citra sekolah dan biaya pendidikan terhadap keputusan siswa.

Tabel 16. Hasil Uji Hipotesis Citra Sekolah Dan Biaya Pendidikan Terhadap Keputusan Siswa.

\begin{tabular}{|c|c|c|c|c|c|c|}
\hline \multicolumn{7}{|c|}{ ANOVA $^{\mathrm{a}}$} \\
\hline \multicolumn{2}{|c|}{ Model } & Sum of Squares & $\mathrm{df}$ & Mean Square & F & Sig. \\
\hline \multirow[t]{3}{*}{1} & Regression & 685.444 & 2 & 342.722 & 62.654 & $.000^{\mathrm{b}}$ \\
\hline & Residual & 530.596 & 97 & 5.470 & & \\
\hline & Total & 1216.040 & 99 & & & \\
\hline & pendent Vari & san Siswa $(Y)$ & & & & \\
\hline & dictors: (Cor & Pendidikan (X2), Cit & ekola & & & \\
\hline
\end{tabular}

Berdasarkan hasil pengujian pada tabel di atas, diperoleh nilai $\mathrm{F}$ hitung $>\mathrm{F}$ tabel atau $(62,654>2,700)$, dengan demikian hipotesis ketiga yang diajukan bahwa terdapat pengaruh yang signifikan atara citra sekolah dan biaya pendidikan terhadap keputusan siswa diterima.

\section{Hasil dan Pembahasan}

\section{Pengaruh Citra Sekolah Terhadap Keputusan Siswa}

Variabel citra sekolah berpengaruh signifikan terhadap keputusan siswa dengan kontribusi sebesar $45,3 \%$ dan sisanya faktor lain yang tidak diteliti. Pengujian hipotesis $t$ hitung $>t$ tabel atau $(7,809>1,984)$ bahwa terdapat berpengaruh signifikan antara citra sekolah terhadap keputusan siswa diterima.

Hasil penelitian ini mendukung hasil penelitian yang dilakukan oleh Endang Rudsianti, Paulus Wardoyo, Sri Purwantini (2019) dengan judul Studi tentang keputusan siswa melanjutkan studi di Sekolah Menengah Kejuruan (SMK) Kabupaten Semarang, dimana dalam penelitiannya menghasilkan kesimpulan bahwa citra sekolah berpengaruh signifikan terhadap keputusan siswa melanjutkan studi di Sekolah Menengah Kejuruan (SMK) Kabupaten Semarang, hal ini diperkuat dengan uji hipotesis diperoleh sig. 0,000<0,05.

Penelitian lainnya yang selaras juga dilakukan oleh Wulan Merdeka Sari, Salman Alfarisy Totalia, Sudarno (2019) dngan judul Pengaruh Citra Sekolah Terhadap Keputusan Memilih Sekolah Pada Siswa SMK Kristen 1 Surakarta, dimana dalam penelitiannya menghasilkan kesimpulan bahwa citra sekolah berpengaruh signifikan terhadap keputusan siswa memilij sekolah di SMK Kabupaten Semarang, hal ini diperkuat dengan uji hipotesis diperoleh sig. 0,000<0,05.

\section{Pengaruh Biaya Pendidikan Terhadap Keputusan Siswa}

Variabel biaya pendidikan berpengaruh signifikan terhadap keputusan siswa dengan kontribusi sebesar 48,5\% dan sisanya faktor lain yang tidak diteliti. Pengujian hipotesis $t$ hitung $>t$ tabel atau $(8,595>1,984)$ bahwa terdapat berpengaruh signifikan antara biaya pendidikan terhadap keputusan siswa diterima.

Hasil penelitian ini mendukung hasil penelitian yang dilakukan oleh Ulil Amri, Yahya (2021) dengan judul Pengaruh Biaya Pendidikan Terhadap Keputusan Memilih Lembaga Pendidikan, dimana dalam penelitiannya menghasilkan kesimpulan bahwa biaya pendidikan berpengaruh signifikan terhadap keputusan memilih lembaga pendidikan dengan uji hipotesis diperoleh sig. $0,000<0,05$

Penelitian lainnya yang selaras juga dilakukan oleh Yosafat Kristianus Bao, dengan judul Pengaruh Reputasi Universitas, Biaya Kuliah, Fasilitas Perkuliahan Terhadap Keputusan Mahasiswa Memilih Program 
Studi Manajemen Universitas Flores Angkatan 2019, dimana dalam penelitiannya menghasilkan kesimpulan bahwa biaya pendidikan berpengaruh signifikan terhadap keputusan mahasiswa memilih Program Studi Manajemen Universitas Flores Angkatan 2019 dengan dibuktikan uji hipotesis diperoleh nilai sig. 0,000 < 0,05 .

\section{Pengaruh Citra Sekolah Dan Biaya Pendidikan Terhadap Keputusan Siswa}

Hasil analisis variabel citra sekolah dan biaya pendidikan berpengaruh signifikan terhadap keputusan siswa dengan persamaan regresi $\mathrm{Y}=9,484+0,331 \mathrm{X} 1+0,440 \mathrm{X} 2$, nilai korelasi sebesar 0,748 artinya kedua variabel independen memiliki hubungan yang kuat terhadap variabel dependen dengan kontribusi pengaruh sebesar $56,4 \%$ sedangkan sisanya sebesar 43,6\% dipengaruhi faktor lain. Pengujian hipotesis diperoleh nilai $\mathrm{F}$ hitung $>$ F tabel atau $(62,654>2,700)$, dengan demikian hipotesis yang menyatakan bahwa terdapat berpengaruh signifikan antara citra sekolah dan biaya pendidikan terhadap keputusan siswa diterima.

Hasil penelitian ini mendukung hasil penelitian yang dilakukan oleh Ade Nia Suryani (2018) dengan judul Pengaruh Brand Image Dan Biaya Pendidikan Terhadap Keputusan Mahasiswa Dalam Memilih Program Studi Manajemen di STIE Rahmaniyah Sekayu Angkatan 2014, dimana dalam penelitiannya menghasilkan kesimpulan bahwa brand image dan biaya pendidikan secara simultan berpengaruh signifikan terhadap keputusan mahasiswa dalam memilih program studi manajemen di STIE Rahmaniyah Sekayu dengan kontribusi pengaruh sebesar 36,3\% dan uji hipotesis diperoleh sig. 0,000<0,05.

Penelitian lainnya yang selaras juga dilakukan oleh Karina Pradityas Putri (2019) dengan judul Analisis Pengaruh Brand Image, Biaya Pendidikan dan Fasilitas Pendidikan Terhadap Keputusan Mahasiswa Melanjutkan Studi Pada Program Diploma III Fakultas Ekonomi Universitas Diponegoro Semarang. Dimana dalam penelitiannya menghasilkan kesimpulan bahwa brand image, biaya pendidikan dan fasilitas pendidikan secara simultan berpengaruh signifikan terhadap keputusan mahasiswa melanjutkan studi pada Program Diploma III Fakultas Ekonomi Universitas Diponegoro Semarang dengan uji hipotesis diperoleh sig. 0,000 < 0,05 .

\section{Simpulan}

Berdasarkan hasil pengujian yang sudah dilakukan, maka dalam penelitian ini menghasilkan kesimpulan sebagai berikut: 1) Terdapat pengaruh yang signifikan antara citra sekolah terhadap keputusan siswa untuk melanjutkan pendidikan ke SMK di wilayah Daerah Istimewa Yogyakarta dengan kontribusi pengaruh sebesar 45,3\% dan pengujian hipotesis diperoleh $t$ hitung $>$ t tabel atau $(7,809>1,984) ; 2)$ Terdapat pengaruh yang signifikan antara biaya pendidikan terhadap keputusan siswa untuk melanjutkan pendidikan ke SMK di wilayah Daerah Istimewa Yogyakarta dengan kontribusi pengaruh sebesar 48,5\% dan pengujian hipotesis diperoleh $\mathrm{t}$ hitung $>\mathrm{t}$ tabel atau $(8,595>1,984) ; 3)$ Terdapat pengaruh yang signifikan antara citra sekolah dan biaya pendidikan secara simultan terhadap keputusan siswa untuk melanjutkan pendidikan ke SMK di wilayah Daerah Istimewa Yogyakarta dengan kontribusi pengaruh sebesar 56,4\% dan sisanya sebesar 43,6\% dipengaruhi faktor lain. Sedangkan uji hipotesis diperoleh nilai F hitung $>$ F tabel atau $(62,654>2,700)$.

Berdasarkan pembahasan dan kesimpulan yang sudah disampaikan di atas, maka penulis memberikan saran sebagai berikut: 1) Pihak sekolah SMK di wilayah Daerah Istimewa Yogyakarta sangat penting penting untuk memilih strategi pemasaran yang diterapkan di sekolah dengan cara lebih meningkatkan kualitas pendidikan yang nantinya lulusannya memiliki kompetensi yang baik agar dapat menyaring lebih banyak lagi minat siswa untuk melanjutkan pendidikan disekolah tersebut; 2) Pihak sekolah SMK di wilayah Daerah Istimewa Yogyakarta hendaknya mampu mencari alokasi dana lain seperti pengajuan beasiswa ke lembagalembaga guna membiayai sekolah siswa dan juga pada akhirnya juga mampu mengurangi beban operasional sekolah sehingga biaya pendidikan yang dibebankan ke siswa dapat diminimalisir dan terjangkau bagi masyarakat.

\section{Referensi}

Algifari. (2015). "Analisis Regresi untuk Bisnis dan Ekonomi”. Yogyakarta: BPFE. Arikunto, Suharsimi (2014). "Prosedur Penelitian Suatu Pendekatan Praktek". Jakarta: Rineka Cipta.

Bao, Yosafat Kristianus. "Reputasi Universitas, Biaya Kuliah, Fasilitas Perkuliahan Dan

Keputusan Mahasiswa Memilih Program Studi Manajemen Universitas Flores: Studi Pada

Mahasiswa Program Studi Manajemen Angkatan 2019.” Analisis Edisi20 Ta.

Edi Sutrisno (2016). Manajemen Sumber Daya Manusia. Jakarta: Prenadamedia Group.

Fandy Tjiptono (2017), Serivce Quality and Satisfiation. Jakarta: Edisi tiga. Andi. 
Freddy Rangkuti (2016) Strategi Promosi Yang Kreatif, Edisi Pertama, Cetakan Pertama Jakarta: Gramedia Pustaka Utama

Griffin R.W., \& Ronald, J.E. (2003). Dasar-Dasar Pemasaran. Jakarta: Raja

Hadi Nafik, Umurul Tri Kresna Multi (2018) Pengaruh Orang Tua Terhadap Keputusan Siswa memilih di SMP Negeri Karangrejo Tahun 2017/2018.

Imam Ghozali (2017). "Aplikasi Analisis Multivariate Dengan Program SPSS". Edisi Kelima. Semarang: Badan Penerbit Undip.

Istijanto (2014) "Riset Sumber Daya Manusia". Jakarta: PT. Gramedia Pustaka

Keller dan Amstrong (2017) "Prinsip-prinsip Pemasaran". Edisi Kedua Belas". Jilid Satu. Jakarta: Erlangga.

Kevin Keller dan Amstrong (2017) Prinsip-prinsip Pemasaran, Edisi Kedua Belas, Jilid Satu, Jakarta: Erlangga.

Kotler (2016) "Manajemen Pemasaran". Edisi Keempat belas, Jakarta: PT. Indeks.

Lupiyadi, Rambat (2016) Manajemen Pemasaran Jasa edisi 2, Jakarta: Salemba Empat.

Mulyono (2018) Konsep Pembiayaan Pendidikan, Yogyakarta: Ar Ruzz Media Grup.

Philip Kotler (2017) Manajemen Pemasaran, Edisi Keempat Belas, Jakarta: PT. Indeks.

Purba Rahkmawati (2018) Analisis Faktor-Faktor Yang Membedakan Pembayaran Pendidikan Satuan Pendidikan SMK Negeri Kota Tebing Tinggi.

Putri, Karina Pradityas (2019). "Analisis Pengaruh Brand Image, Biaya Pendidikan, Dan Fasilitas Pendidikan Terhadap Keputusan Mahasiswa Melanjutkan Studi Pada Program Diploma III Fakultas Ekonomi Universitas Diponegoro Semarang." Http://Eprints.Undip.Ac.Id/30905/1/JURNAL.Pdf.

Rivandi, Muhammad. 2021. "Pengaruh Motivasi, Biaya Pendidikan Dan Lama Pendidikan Terhadap Minat Mahasiswa Akuntansi Mengikuti Pendidikan Akuntansi (Ppak) Di Universitas Dharma Andalas." Jurnal Ekonomi Dan Bisnis Dharma Andalas Volume 23.

Santoso, Singgih (2015). "Menguasai Statistik Multivariat”. Jakarta: PT Elex Media Komputindo.

Sudjana (2014) "Metode Statistika", Bandung: Tarsido.

Sugiyono (2017), "Metode Penelitian Administrasi: dilengkapi dengan Metode $R \& D$ ". Bandung: Alfabeta.

Suhartanto (2014). "Metode Riset Pemasaran". Bandung: Alfabeta

Supardin, Ninik Indrawati, Walipah. "Pengaruh Kualitas Pelayanan, Biaya Pendidikan, Dan Kelompok Referensi Terhadap Keputusan Mahasiswa Pendidikan Ekonomi Memilih Pada Program Studi Pendidikan Ekonomi." Jurnal Riset Pendidikan Ekonomi (JRPE).

Supriyadi (2010). Strategi Belajar Mengajar. Yogyakarta: Pustaka Pelajar.

Yohandri, Trian (2017) "Pengaruh Persepsi Tentang Fasilitas, Biaya Pendidikan, Kualitas Dan Lokasi Terhadap Keputusan Siswa Memilih Sekolah.” JEE (Jurnal Edukasi Ekobis) Volume 2 